\title{
Unconventional Monetary Policy and International Risk Premia
}

Rogers, John H., Chiara Scotti, and Jonathan H. Wright

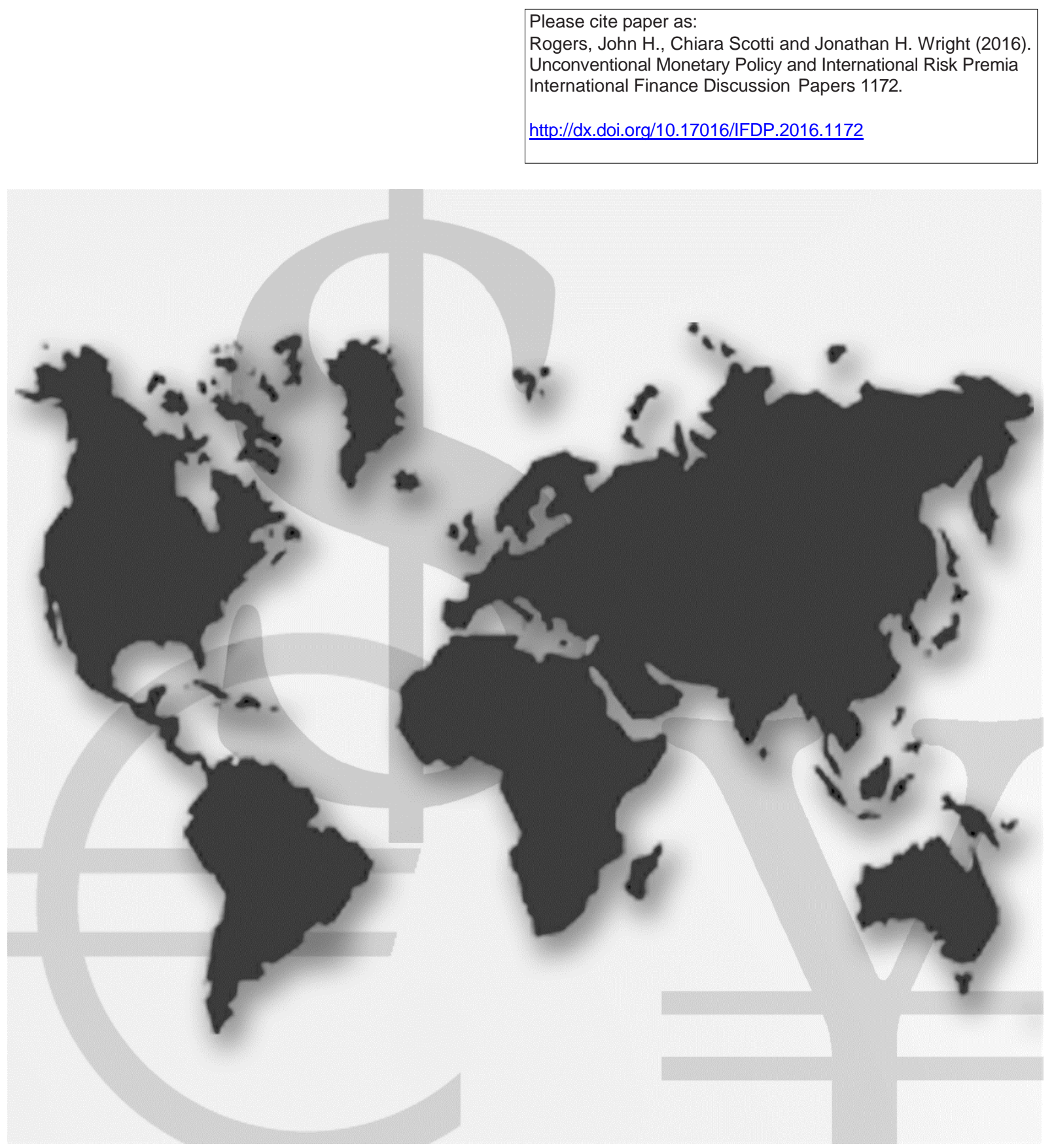

\section{International Finance Discussion Papers}

Board of Governors of the Federal Reserve System

Number 1172

June 2016 
Board of Governors of the Federal Reserve System

International Finance Discussion Papers

Number 1172

June 2016

\title{
Unconventional Monetary Policy and International Risk Premia
}

\author{
John H. Rogers \\ Federal Reserve Board \\ Chiara Scotti \\ Federal Reserve Board \\ Jonathan H. Wright \\ Johns Hopkins
}

NOTE: International Finance Discussion Papers are preliminary materials circulated to stimulate discussion and critical comment. References in publications to International Finance Discussion Papers (other than an acknowledgment that the writer has had access to unpublished material) should be cleared with the author or authors. Recent IFDPs are available on the Web at www.federalreserve.gov/pubs/ifdp/. This paper can be downloaded without charge from Social Science Research Network electronic library at http://www.ssrn.com/. 


\title{
Unconventional Monetary Policy and International Risk Premia*
}

\author{
John H. Rogers ${ }^{\dagger} \quad$ Chiara Scotti ${ }^{\ddagger} \quad$ Jonathan H. Wright ${ }^{\S}$ \\ May 31, 2016
}

\begin{abstract}
We assess the relationship between monetary policy, foreign exchange risk premia and term premia at the zero lower bound. We estimate a structural VAR including U.S. and foreign interest rates and exchange rates, and identify monetary policy shocks through a method that uses these surprises as the crucial "external instrument" that achieves identification without having to use implausible short-run restrictions. This allows us to measure effects of policy shocks on expectations, and hence risk premia. U.S. monetary policy easing shocks lower domestic and foreign bond risk premia, lead to dollar depreciation and lower foreign exchange risk premia. We present some evidence that U.S. monetary policy easing surprises at the ZLB shift options-implied skewness in the direction of dollar depreciation and also reduce the demand for the liquidity of short-term U.S. Treasuries. Both of these channels should lower foreign exchange risk premia.
\end{abstract}

\footnotetext{
${ }^{*}$ The views expressed in this paper are solely the responsibility of the authors and should not be interpreted as reflecting the views of the Board of Governors of the Federal Reserve System or of any other person associated with the Federal Reserve System. We thank Charles Engel for very helpful comments on an earlier draft and Mark Berry, Eric English, Qian Li, and J Seymour for valuable research assistance. All errors are our sole responsibility.

${ }^{\dagger}$ International Finance Division, Federal Reserve Board, Washington DC 20551; john.h.rogers@frb.gov.

${ }^{\ddagger}$ Division of Financial Stability, Federal Reserve Board, Washington DC 20551; chiara.scotti@frb.gov.

${ }^{\S}$ Department of Economics, Johns Hopkins University, Baltimore MD 21218; wrightj@jhu.edu.
} 


\section{Introduction}

In the wake of the Great Recession, the world's largest central banks set short term nominal interest rates to the effective zero lower bound (ZLB) and began adopting unconventional monetary policies, such as forward guidance and large scale asset purchases. These policies have renewed interest in the role of monetary policy in explaining the dynamics of exchange rates, and domestic and foreign interest rates. By affecting exchange rates and foreign interest rates, monetary policy shifts are a potential source of unintended spillovers onto other countries (Engel, 2013). Indeed, these issues are old ones in empirical international finance, predating the recent period of unconventional monetary policy (Eichenbaum and Evans, 1995; Kim, 2001; Kim and Roubini, 2000; Faust et al., 2003), but the answers are potentially different at the ZLB.

A large strand of the literature addresses these questions using a vector autoregression (VAR) in interest rates (domestic and foreign) and exchange rates. The identification of monetary policy shocks is however contentious. Several papers achieve identification by positing a recursive ordering in which it is assumed that U.S. monetary policy shocks have no immediate effect on foreign interest rates (Eichenbaum and Evans, 1995; Kim and Roubini, 2000). ${ }^{1}$ However, there is considerable evidence from the "event-study" literature showing that global interest rates and exchange rates respond immediately and substantively to U.S. monetary policy shocks (Andersen et al., 2003, 2007; Faust et al., 2007; Ehrmann and Fratzscher, 2003, 2005; Bredin et al., 2010; Hausman and Wongswan, 2011; Rogers et al., 2014; Wright, 2012; Kiley, 2013; Gilchrist et al., 2014). In this paper, we adopt a different and more credible approach to identification of structural monetary policy shocks in a VAR. We use a variant of the method of external instruments (Stock and Watson, 2012; Olea et al., 2013; Gertler and Garadi, 2015; Mertens and Ravn, 2013), where the ordering of the variables does not matter in identification. This structural VAR then allows us to trace out the dynamic effects of a monetary policy shock on domestic and foreign interest rates, as well as exchange rates. As a by-product, we can then compute the

\footnotetext{
${ }^{1}$ There are of course exceptions (Faust and Rogers, 2003; Scholl and Uhlig, 2008; Bjornland, 2009; Bouakez and Normandin, 2010). Faust and Rogers (2003) first studied these issues using a technique that allowed a relaxation of such dubious assumptions, Scholl and Uhlig (2008) use a related sign restrictions procedure, while Bjornland (2009) and Bouakez and Normandin (2010) use long run zero restrictions and identification through heteroskedasticity, respectively. In all cases, identification works through shocks to the target Fed Funds rate in these pre-ZLB papers.
} 
effects of the monetary policy shock on financial market risk premia: the domestic term premium, the foreign term premium, and the foreign exchange risk premium. We focus primarily on the effects of U.S. monetary policy shocks, but also include a brief analysis of the impact of Bank of England, European Central Bank, and Bank of Japan monetary policy shocks.

This framework gives us a complete picture of the international effects of unconventional monetary policy on asset prices and risk premia. It is clear that foreign exchange risk premia are time-varying (Fama, 1984; Engel, 1996), but the existing empirical results on whether monetary policy surprises affect foreign exchange risk premia are more mixed (Kim and Roubini, 2000; Faust and Rogers, 2003; Scholl and Uhlig, 2008; Bjornland, 2009; Bouakez and Normandin, 2010). In other words, it is clear that uncovered interest parity (UIP) does not hold unconditionally, but the existing evidence is less clear on whether UIP holds conditional on monetary policy surprises. We revisit this issue in the context of unconventional monetary policy.

The plan for the remainder of this paper is as follows. In the next section we describe the data we use in the empirical analysis. In section 3, we describe our VAR methodology. In section 4, we present empirical results. Section 5 concludes.

\section{Data}

We use a wide range of financial and macroeconomic data at different frequencies. To the extent possible, we try to incorporate intradaily information into our analysis.

We measure U.S. monetary policy shocks at the ZLB as in Rogers et al. (2014). Specifically, the surprise is the change in five-year Treasury futures from 15 minutes before the time of FOMC announcements to 1 hour 45 minutes afterwards on the days of FOMC announcements. A positive value of the monetary policy surprise is normalized to be an expansionary change, i.e., a drop in the yield. These monetary policy surprises are computed from October 2008 to December 2015, which is the entire period of the ZLB in the U.S. The dates of the unconventional monetary policy period correspond to those in Rogers et al. (2014) updated to the end of 2015. There are 69 FOMC announcements in this period.

In the VAR analysis, we use three-month, five-year and ten-year U.S. zero-coupon bond yields, the log foreign exchange rate, the three-month and ten-year foreign zerocoupon bond yields, the log of U.S. employment and core CPI, and the BAA-Treasury 
spread (a widely-used credit spread (Christiano et al., 2014)). The zero-coupon bond yields all come from the dataset of Wright (2011), updated to the end of 2015, augmented with Italian zero-coupon bond yields, obtained from the BIS. Exchange rates are defined throughout as dollars per unit of foreign currency. The VAR is run at the monthly frequency (using end-of-month data for asset prices), but we have daily data on the zero-coupon yields and intradaily data on foreign exchange rates, and we will use these higher-frequency data in identifying our structural VAR, as explained below. We choose the U.K., euro area, and Japan as our foreign countries. The sample period is January 1990 to December 2015 (except January 1999 to December 2015 where the euro area is the foreign country).

\section{VAR Analysis}

We start from an assumption that there is an $n \times 1$ vector of monthly variables, $Y_{t}$ including interest rates and exchange rates, that follows a $\operatorname{VAR}(p)$ :

$$
A(L) Y_{t}=\varepsilon_{t}
$$

where $\varepsilon_{t}$ denote the reduced form forecast errors which are $N(0, \Sigma)$. All variables are linearly detrended. We further assume that these reduced form errors can be related to a set of underlying structural shocks:

$$
\varepsilon_{t}=R \eta_{t}
$$

where $\eta_{t}$ is a vector of structural shocks. Partition $\eta_{t}$ as $\left(\eta_{1 t}, \eta_{2 t}^{\prime}\right)^{\prime}$ where $\eta_{1 t}$ is the monetary policy shock and $\eta_{2 t}$ is an $(n-1) x 1$ vector of other shocks. The fact that the monetary policy shock is ordered first is for notational convenience only. The ordering of variables is irrelevant as a Choleski decomposition will not be used for identification.

Our approach to identification instead involves the method of external instruments. We define $Z_{t}$ as the intraday change in a domestic interest rate in a short window bracketing the time of any monetary policy announcement in month $t$. Here our external instrument $Z_{t}$ is the monetary policy surprise described in section 2 : the change in yields on five-year Treasury futures from 15 minutes before the time of FOMC announcements to 1 hour 45 minutes afterwards on the days of FOMC 
meetings. In the VAR, if there is no monetary policy announcement in that month, then $Z_{t}=0$. If there are multiple monetary policy announcements, then it is the sum of the intraday changes bracketing all of those announcements.

We make a number of assumptions. Our first assumption is that $Z_{t}$ is correlated with the monetary policy shock and uncorrelated with all other structural shocks:

Assumption A1: $E\left(\eta_{1 t} Z_{t}\right)=\alpha$ and $E\left(\eta_{2 t} Z_{t}\right)=0$.

We further define $W_{t}$ as a vector of changes in the elements of $Y_{t}$ in daily or intradaily windows bracketing the time of any monetary policy announcement in month $t .^{2}$ For any element of $Y_{t}$ for which daily or intradaily data are not available (i.e. macro variables), set the corresponding element of $W_{t}$ to the reduced form shock in $\varepsilon_{t}$. Our second assumption is that any shocks to $Y_{t}$ that occur away from the time of the monetary policy announcement cannot be correlated with the jump that is associated with the monetary policy news:

Assumption A2: $E\left(Z_{t}\left(\varepsilon_{t}-W_{t}\right)\right)=0$.

Clearly assumption A2 implies that $E\left(Z_{t} W_{t}\right)=E\left(Z_{t} \varepsilon_{t}\right)$. In conjunction with assumption $\mathrm{A} 1$, it implies that $E\left(Z_{t} W_{t}\right)=\alpha R_{1}$, where $R_{1}$ is the first column of $R$. Our third assumption is a standard sign restriction used by Faust (1998) and Uhlig (2005) and many others:

Assumption A3: An easing monetary policy surprise cannot contemporaneously lower prices or employment.

Under these assumptions, $R_{1}$ is identified only up to scale and sign. We consider a monetary policy shock that is scaled to lower U.S. five-year yields by 25 basis points. We estimate the VAR by Bayesian methods, similar to those proposed by Caldara and Herbst (2016). Write the VAR in equation (1) in the form $Y=X B+\varepsilon$ where $X$ is $T \mathrm{x} k$, and let $\hat{B}$ denote the OLS estimate of $B$ (which contains all the parameters in $A(L))$. Write the regression of the $i$ th element of $W_{t}$ on $Z_{t}$ as $W_{i t}=\gamma_{i} Z_{t}+u_{i t}$, where $\operatorname{Var}\left(u_{i t}\right)=\omega_{i}^{2}$. Define $W_{i}=\left(W_{i 1}, W_{i 2}, \ldots W_{i T}\right)^{\prime}, \gamma=\left(\gamma_{1}, \gamma_{2}, \ldots \gamma_{n}\right)^{\prime}$ and $\omega=$ $\left(\omega_{1}, \omega_{2}, \ldots \omega_{n}\right)^{\prime}$. We use a diffuse prior for $\{B, \Sigma\}$ that is proportional to $|\Sigma|^{-(n+1) / 2}$.

\footnotetext{
${ }^{2}$ For some asset prices, we have daily data and so these elements of $W_{t}$ are constructed as daily changes summed over all announcement days in the month. For other asset prices, we have intradaily data and so these elements of $W_{t}$ are constructed as the changes from 15 minutes before the FOMC announcement to 1 hour 45 minutes afterwards, summed over all announcement days in the month. If there is no FOMC announcement in a given month, the elements of $W_{t}$ corresponding to any asset prices are all set to zero.
} 
The priors for $\left\{\gamma_{i}, \omega_{i}^{2}\right\}_{i=1}^{n}$ are likewise diffuse, proportional to $\omega_{i}^{-2}$. Apart from the sign restriction, the posterior for the parameters is:

$$
\begin{gathered}
p(B, \Sigma, \gamma, \omega \mid D)=p(B, \Sigma \mid D) p(\gamma, \omega \mid B, \Sigma, D) \\
\propto|\Sigma|^{-(T+n+1) / 2} \exp \left(-\frac{1}{2} \operatorname{tr}\left(\Sigma^{-1}(Y-X B)^{\prime}(Y-X B)\right)\right) \\
\Pi_{i=1}^{n} \omega_{i}^{-T-2} \exp \left(-\frac{1}{2 \omega_{i}^{2}}\left(W_{i}-\gamma_{i} Z\right)^{\prime}\left(W_{i}-\gamma_{i} Z\right)\right)
\end{gathered}
$$

where $D$ denotes the available data (consisting of both $Y_{t}$ and the high-frequency data in $Z_{t}$ and $W_{t}$ ). We take draws from the posterior in equation (3) from the following simulation scheme:

1. Draw a proposal for $\Sigma$ from an inverse-Wishart distribution with parameters $\left((Y-X \hat{B})^{\prime}(Y-X \hat{B}), T-k\right)$ and for $\operatorname{vec}(B)$ from a $N\left(\operatorname{vec}(\hat{B}), \Sigma \otimes\left(X^{\prime} X\right)^{-1}\right)$. This is the posterior for the VAR parameters based on $Y_{t}$ alone. Let $\Sigma^{*}$ and $B^{*}$ denote these proposals. Accept the proposal with probability:

$$
\min \left(\frac{p\left(B^{*}, \Sigma^{*}, \gamma, \omega\right)}{p(B, \Sigma, \gamma, \omega)}, 1\right) .
$$

Otherwise keep the existing draws of $\Sigma$ and $B$ (Metropolis-Hastings step).

2. Let $\hat{\gamma}_{i}$ be $\left(Z^{\prime} Z\right)^{-1} Z^{\prime} W_{i}$. Draw $\omega_{i}^{2}$ from an inverse-Wishart distribution with parameters $\left(\left(W_{i}-Z \hat{\gamma}_{i}\right)^{\prime}\left(W_{i}-Z \hat{\gamma}_{i}\right), T-1\right)$ for each $i$ from 1 to $n$. $W_{i}$ is taken from high-frequency data if available, or else is calculated as the $i$ th element of $Y-B X$.

3. Draw the $i t h$ element of $R_{1}$ from a $N\left(\hat{\gamma}_{i}, \omega_{i}^{2}\left(Z^{\prime} Z\right)^{-1}\right)$ for each $i$.

4. Normalize $R_{1}$ to lower U.S. five-year yields by 25 basis points.

5. Reject the draw if it does not satisfy the sign restriction (Assumption A3).

6. Repeat steps 1-5 to build up the posterior distribution, discarding an initial burnin sample.

This allows us to trace out the effect of the monetary policy shock on $E_{t}\left(Y_{t+j}\right)$. The methodology essentially involves the external instruments approach, but we extend it 
by using the fact that data at higher-than-monthly frequency are available for some elements of $Y_{t}$. Thus, the methodology also draws on the event study approach, as we use high-frequency data around announcements in both $Z_{t}$ and $W_{t}{ }^{3}$ However, because we embed this in an identified VAR, we can trace out the full dynamic effect of the monetary policy shock, not just the instantaneous effect as is standard in the event-study literature.

We let $Y_{t}$ be a vector of 9 variables: three-month, five-year and ten-year U.S. zero-coupon bond yields, the log foreign exchange rate, the three-month and tenyear foreign zero-coupon bond yields, and the log of U.S. employment and core CPI, and the BAA-Treasury spread. A separate VAR is run for each foreign country: United Kingdom, euro area, and Japan. For $W_{t}$, we observe daily data on the zerocoupon yields and intradaily data on the foreign exchange rate, and so we construct the variable $W_{t}$ as described in footnote 2. The sample period is January 1990 to December 2015 (except January 1999 to December 2015 where the euro area is the foreign country). However, because we are interested in the effects of announcements during the era of unconventional monetary policy, for our external instrument $Z_{t}$, we only consider announcements from October 2008 to December 2015 - that is steps 2 and 3 of the simulation scheme are run using this subsample alone.

The VAR immediately allows us to trace out the effects of the monetary policy shock on future values of $Y_{t}$. But, because expectations can be measured from the VAR, it also allows us to work out the effects of the monetary policy shock on various financial market risk premia. These include the domestic term premium, defined as:

$$
T P_{t}(m)=r_{t}(m)-E_{t}\left(\frac{1}{m / 3} \sum_{i=0}^{m / 3-1} r_{t+3 i}(3)\right),
$$

the foreign term premium, defined as:

$$
T P_{t}^{*}(m)=r_{t}^{*}(m)-E_{t}\left(\frac{1}{m / 3} \Sigma_{i=0}^{m / 3-1} r_{t+3 i}^{*}(3)\right),
$$

and the average annualized foreign exchange risk premium over the next $m$ months,

\footnotetext{
${ }^{3}$ The high-frequency data in $W_{t}$ permits much tighter inference. We could simply use the full vector of reduced form residuals as $W_{t}$, and this would be the standard external instruments approach, but the resulting confidence intervals for impulse responses would be much wider.
} 
defined as:

$$
F P(m)=\frac{1}{m / 3} \Sigma_{i=0}^{m / 3-1}\left[E_{t} r_{t+3 i}^{*}(3)-E_{t} r_{t+3 i}(3)+400\left(E_{t} s_{t+3 i+3}-E_{t} s_{t+3 i}\right)\right] .
$$

For these definitions, the short rate is a three-month interest rate but the time subscripts refer to months, consistent with the VAR. Examining the dynamic effect of the monetary policy shock on each of these risk premia gives us additional insight into the channels by which monetary policy may be effective.

Our paper is related to the large and fast-growing literature on the effects of unconventional monetary policy. Authors such as Gagnon et al. (2011), Krishnamurthy and Vissing-Jorgenson (2011) and Christensen and Rudebusch (2012) have examined the change in government bond yields and term premia - as estimated by affine term structure models - on the days of specific unconventional monetary policy announcements. Wright (2012) and Rogers et al. (2014) used a methodology based on identification through heteroskedasticity to trace out the effects of monetary policy surprises on interest rates. Kiley (2013) estimates the one-day effects of monetary policy surprises on foreign and domestic long-term interest rates and on exchange rates. He defines the UIP deviation as the hold-to-maturity excess returns on the foreign long bond over the domestic long bond, i.e. $\frac{m}{12}\left(r_{t}^{*}(m)-r_{t}(m)\right)+100\left(E_{t+m} s_{t+m}-s_{t}\right)$. Under the assumption that $m$ is sufficiently large that the monetary policy surprise has no effect on $E_{t+m} s_{t+m}$, Kiley (2013) finds that monetary policy surprises do not significantly affect the UIP deviation defined in this way. The present paper is however the first to use a vector autoregression identified with external instruments to measure the full dynamic effects of unconventional monetary policy surprises on foreign and domestic interest rates, and exchange rates. As a by-product, this then gives us estimates of the effects of monetary policy surprises on the full set of financial market risk premia given by equations (4)-(6).

It should also be emphasized that several papers, including Gagnon et al. (2011), Krishnamurthy and Vissing-Jorgenson (2011) and Christensen and Rudebusch (2012), have analyzed the effects of specific unconventional monetary policy announcements, assuming that they were entirely unanticipated by the markets. This is a reasonable assumption in relation to some announcements, for example during the first phase of quantitative easing in the United States (QE1). But many other unconventional monetary policy announcements have been partially anticipated by markets. This 
is not a problem for our methodology, as long as there is some news coming out in monetary policy announcements. At the same time, it should be emphasized that the external instruments methodology used in this paper only identifies monetary policy up to a scale factor. Also, we do not separate out the effects of monetary policy operating via forward guidance and asset purchases - rather we are estimating the total effects of monetary policy news.

\section{Empirical Results}

First, we check instrument relevance. The "first stage" regression is a regression of the daily change in five-year yields onto the instrument. The test statistic is 301 - far above the cutoff in the weak instruments literature (Stock and Yogo, 2005; Stock et al., 2002). Weak instruments are not an issue in this application.

Figure 1 shows the effect of the monetary policy shock on the exchange rate at different horizons (all impulse responses are shown out to 60 months). The figure shows the posterior median and 68 percent Bayesian posterior intervals, which we henceforth refer to as the estimates and confidence intervals. The expansionary U.S. monetary policy shocks cause the dollar to depreciate significantly. The effect tends to wear off over time, but slowly. Unlike Eichenbaum and Evans (1995) (who considered VARs with recursive identification), we find no evidence of delayed overshooting. The exchange rate effect is significantly positive for at least about a year for all three foreign currencies - here and henceforth we refer to effects as significantly positive/negative if the Bayesian confidence interval covers only positive/negative values.

Figure 2 shows the effect of the U.S. monetary policy shock on the foreign interest rates, both three-month and ten-year. For all three countries, the monetary policy shock has little effect on three-month yields, but has a significantly negative effect on ten-year interest rates at short horizons. The finding that monetary policy spillovers are greatest for longer term interest rates seems unsurprising because the ZLB was binding in the United Kingdom and Japan for this period, and so no easing action by the Fed can lower their short rates much further, while the European Central Bank was close to the ZLB and reached it near the end of the sample. The estimated instantaneous effect on foreign ten-year interest rates is slightly more than 10 basis points for the United Kingdom and Germany and a bit less for Japan.

Figure 3 shows the effect of the monetary policy shock on the expected foreign 
exchange excess returns $(F P(m))$ at different horizons. The monetary policy shock is

estimated to significantly lower the foreign exchange risk premium, at least at some horizons, for both the pound and the euro.

Table 1 shows the estimated instantaneous effect of the monetary policy shock on the ten-year term premium in the United Kingdom, Germany and Japan. The point estimates of the effects on term premia are roughly the same as the effects on the ten-year yield - the effect on foreign long bond yields is estimated to be largely due to term premia. The confidence intervals are wide, but do not bracket zero.

From the VAR results so far, we conclude that U.S. monetary policy easing shocks depreciate the dollar, lower foreign term premia, and lower foreign exchange risk premia.

\subsection{Analysis of Foreign Exchange Risk Premia}

The evidence that we find against conditional UIP is that an easing monetary policy surprise lowers the foreign exchange risk premium. This is the opposite sign from what has been found in earlier VAR work (e.g. Eichenbaum and Evans (1995)).

A recent study (International Monetary Fund, 2013) finds that with unconventional monetary policy, surprise easings of U.S. policy shift foreign exchange riskreversals in the direction of dollar depreciation. A risk-reversal is an options position which is long an out-of-the-money call option and short an equivalently out-of-themoney put option. It is quoted as the annualized implied volatility on the call option less that on the put option. It is a measure of options-implied skewness.

Motivated by this finding, on all U.S. monetary policy announcement days, we regressed the change in foreign exchange risk-reversals at various maturities onto our measure of the U.S. monetary policy surprise, for all 69 FOMC announcement days from October 2008 to December 2015. The results are shown in Table 2. The coefficients are significantly positive (at the 5 percent level) for all currency-maturity pairs. Recall that throughout this paper the foreign exchange rate is defined as dollars per unit foreign currency. This means that, like International Monetary Fund (2013), we find that monetary policy easings cause the options market to view the prospects for future exchange rate changes as being more skewed in the direction of dollar depreciation. If investors are risk-averse, this in turn might make them want to shift from dollar-denominated to foreign-currency-denominated assets. As investors 
cannot all do so, in equilibrium the expected return on foreign-currency assets must fall. In other words, investors may demand a bigger risk premium to hold currencies that are more likely to depreciate sharply than to appreciate sharply. If so, and if unconventional monetary policy easings shift skewness in the direction of sharp dollar depreciations, it would reduce the foreign currency risk premium. This is at least consistent with our finding that unconventional easing monetary policy surprises lower the foreign exchange risk premium. Note that International Monetary Fund (2013) found this pattern of monetary policy surprise easings leading to options-implied skewness only for unconventional monetary policy.

This potential explanation for the evidence that we find against UIP conditional on monetary policy shocks is related to several recent papers that have proposed a skewness-related interpretation of the unconditional failure of UIP. Brunnermeier et al. (2009) and Farhi and Gabaix (2014) find that risk-reversals imply that the distribution of future exchange rate returns is skewed in the direction of depreciation of high interest currencies. They argue that, as compensation for this risk, investors demand positive expected returns to induce them to hold high interest currencies, explaining the unconditional failure of UIP. We are using a similar argument to explain the failure of UIP conditional on unconventional monetary policy surprises.

Other recent theoretical explanations of the UIP puzzle include Engel (forthcoming) and Backus et al. (2010). Engel argues that it is unlikely that a pure foreign exchange risk premium could explain the pattern of excess returns that he documents in a (mostly pre-ZLB) sample period ending in October 2009, and offers a model based on liquidity returns. Backus et al. (2010) investigate how different specifications of domestic and foreign Taylor rules for monetary policy can resolve the UIP puzzle. International Monetary Fund (2013) argues that unconventional monetary policy helped to improve market functioning. Our finding that unconventional easing surprises lower the foreign exchange risk premium, as we define it, could perhaps represent diminished demand for the liquidity of short-term U.S. Treasuries amid improved market functioning.

To consider this possibility further, we took the spread of three-month Eurodollar rates over corresponding maturity Treasury bill rates, the so-called TED spread as a measure of market functioning (high values correspond to heightened demand for the liquidity and safety of Treasury bills). We regressed the change in the TED spread onto our measure of the U.S. monetary policy surprise for all announcement days 
from October 2008 to December 2015 . We estimate that a U.S. monetary policy easing surprise (meaning a one percentage point drop in five-year yields bracketing the FOMC announcement) lowers the TED spread by 0.19 percentage points, with a t-statistic of 1.65. This is barely significant at the 10 percent level. This represents suggestive evidence that unconventional easing surprises may lower the foreign exchange risk premium, as we define it, via diminished demand for the liquidity of short-term U.S. Treasuries.

\subsection{Effects of Monetary Policy on Domestic Term Premia}

Our main focus in this paper is on the effects of monetary policy surprises on international risk premia, but our methodology also gives estimates of the effects of monetary policy surprises on domestic term premia. We estimated the effects of monetary policy surprises on U.S. term premia in the VARs of the previous section. The precise results of course depend on which foreign country is included, but are qualitatively similar to each other, and to the results in a VAR that includes no foreign variables. Consequently, for the purpose of estimating effects on domestic term premia, we report results from a VAR in U.S. three-month, five-year and ten-year interest rates, the log of employment and core CPI, and the BAA-Treasury spread.

The results are shown in Table 3 . The monetary policy shock that lowers the fiveyear yield by 25 basis points is estimated to lower the corresponding term premium by 21 basis points, essentially explaining the full drop in yields. Results for the ten-year term premium are similar.

\subsection{Comparison with pre-ZLB era}

The methodology that we propose applies in principle to the pre-ZLB era as well. Indeed, monetary policy in the pre-ZLB and ZLB eras have much in common. Kuttner (2001) and Gürkaynak et al. (2005) both show that over the past twenty years,

\footnotetext{
${ }^{4}$ In this exercise, care must be taken with regard to the timing at which the asset prices are recorded. Eurodollar rates are measured at 11am London time, which is very early in the morning in New York. Treasury bill rates are measured at the close of business in the United States. All FOMC announcements occur between these two times. Consequently, we measure the change in the TED spread bracketing the FOMC announcement as the change in the Eurodollar rate from the day of the announcement to the day after the announcement less the change in the Treasury bill yield from the day before the announcement to the day of the announcement.
} 
FOMC announcements concerning the target federal funds rate have been largely anticipated by the market. Instead, FOMC announcements and communications have been important mainly because of information that they contain about the future path of monetary policy. But this is just a form of forward-guidance, although less explicit than during the ZLB era.

In Figures 4, 5 and 6, we show the estimated effects of the monetary policy shock on the exchange rate, foreign interest rates, and expected foreign exchange returns, where the VAR is estimated as before, but the external instrument is the change in the fourth eurodollar futures contract from 15 minutes before the time of FOMC announcements to 1 hour 45 minutes afterwards, and the VAR residuals are regressed on this external instrument over the period from February 1994 to September 2008.

The effects of monetary policy surprises over the pre-ZLB era estimated in Figures 4-6 are generally similar to those in Figures 1-3. A 25 basis point reduction in five-year yields that is driven by monetary policy leads to dollar depreciation and lower interest rates abroad. But there are some differences. The point estimates of the exchange rate effects are smaller in the pre-ZLB sample. Also, in the pre-ZLB sample, threemonth U.K. and Japanese interest rates are significantly lowered. The point estimates of the effects on foreign ten-year rates are smaller in the pre-ZLB sample. Finally, there is no statistically significant effect on the foreign exchange risk premium in the pre-ZLB sample for any of the three currencies.

Table 4 shows the estimated effect of the U.S. monetary policy shock on the ten-year term premium in the United Kingdom, Germany and Japan in the pre-ZLB sample. The effect is not statistically significant for Japan, but is significantly negative for the United Kingdom and Germany. Overall the evidence that U.S. monetary policy shocks affect foreign term premia seems a little weaker over the pre-ZLB sample.

\subsection{Foreign Monetary Policy Surprises}

We applied precisely the same methodology to the case where the home country is the United Kingdom, the euro area or Japan. For the United Kingdom and Japan, the

variables in the VAR, $Y_{t}$, consist of three-month, five-year and ten-year U.K./Japanese zero-coupon bond yields, the log foreign exchange rate, the three-month and tenyear U.S. zero-coupon bond yields, and U.K./Japanese unemployment and log CPI. The external instruments are now intraday changes in U.K. or Japanese ten-year 
government bond yields on monetary policy announcement days. The monetary policy surprise is normalized to lower U.K./Japanese five-year bond yields by 25 basis points. For the euro area, the variables in the VAR consist of three-month, fiveyear and ten-year German zero-coupon bond yields, the log foreign exchange rate, the three-month and ten-year U.S. zero-coupon bond yields, German unemployment and $\log$ CPI, and five-year zero-coupon Italian bond yields. The external instrument is the spread between Italian and German yields, and the monetary policy shock is normalized to lower five-year Italian yields by 25 basis points. The somewhat different treatment of euro area monetary policy surprises is because, over this unusual period, accommodative actions of the ECB were clearly aimed at lowering government bond yields such as Italy and other countries whose sovereign bond markets were coming under significant pressure, rather than German bond yields. As in the U.S. framework, the sample period is January 1990 to December 2015 for the VAR estimation of the residuals (except January 1999 to December 2015 for the euro area). For our external instrument $Z_{t}$, we only consider announcements during the unconventional monetary policy period - the dates of U.K., euro-area and Japanese unconventional monetary policy announcements correspond to those in Rogers et al. (2014) updated to the end of $2015 .^{5}$

Figure 7 shows the estimated effects of U.K., euro-area, and Japanese monetary policy shocks on their respective exchange rates. The Bank of England monetary policy easing that lowers five-year U.K. yields by 25 basis points is estimated to lead to pound depreciation viz-a-viz the dollar that is significant for about a year. The ECB monetary policy easing that lowers Italian five-year yields by 25 basis points leads to a short-lived but statistically significant appreciation of the euro, while the corresponding Bank of Japan monetary policy easing has no significant exchange rate effect. The finding that ECB monetary policy easing leads the euro to appreciate may seem surprising, but recall that the euro was in danger of falling apart for most of our sample period. This is presumably the reason why actions that lowered Italian-German spreads, which we interpret as monetary policy easings, led to euro appreciation. Note that the January 2015 ECB announcement of larger-than-expected quantitative easing was accompanied by euro depreciation, and commentary attributed much

\footnotetext{
${ }^{5}$ The unconventional monetary policy announcements are defined as all monetary policy announcements since October 2008, August 2007 and January 2000 for the Bank of England, ECB and Bank of Japan, respectively.
} 
of the depreciation of the euro in late 2014 to building expectations that the ECB would embark on a full-blown quantitative easing program. This however came near the end of our sample when concerns about the viability of the euro had ebbed. We conjecture that going forward ECB monetary policy easing surprises will lead to euro depreciation, unless substantial concerns of a disintegration of European monetary union resume.

Figure 8 shows the estimated effects of U.K., euro-area and Japanese monetary policy shocks on U.S. interest rates. The U.K. and Japanese monetary policy shocks significantly lower U.S. ten-year yields for a few quarters. The euro area easing shock actually raises U.S. yields. Again this is probably because ECB easing shocks raised the chances of the survival of the euro and reduced safe-haven flows into Treasuries.

Figure 9 shows the estimated effects of U.K., euro area, and Japanese monetary policy shocks on the foreign exchange risk premium. Foreign monetary policy easings are estimated to raise the foreign exchange risk premia, but significantly only for the euro area. These foreign exchange risk premia are defined from the perspective of the foreign country. For example, the euro area panel shows the effect of the ECB monetary policy easing on expected future U.S. short rates less expected future German short rates, adjusted for expected changes in the euro-dollar exchange rate. From this and our earlier results on the effects of U.S. monetary policy easings, we can conclude that to the extent that conditional UIP fails, it is that monetary policy easing shocks anywhere shifts the foreign exchange risk premium in favor of U.S. interest rates.

Finally, the U.K. monetary policy shock is estimated to lower the ten-year U.K. term premium by 27 basis points (confidence interval: -30 to -24 basis points). The ECB monetary policy surprise lowers the ten-year German term premium by 2 basis points (confidence interval: -4 to -1 ). The Japanese monetary policy shock is estimated to lower the ten-year Japanese term premium by 30 basis points (confidence interval: -39 to -24 basis points).

\section{Conclusion}

We assess the relationship between monetary policy and foreign exchange risk premia and term premia at the zero lower bound, employing a structural VAR analysis, using changes in yields in short windows bracketing monetary policy announcements 
as an external instrument. This represents a different and more credible approach to identification of structural monetary policy shocks, one that is well-suited to analyzing policy at the ZLB. We find that U.S. monetary policy easing shocks during the ZLB period lower domestic and foreign bond risk premia, lead to dollar depreciation and lower foreign exchange risk premia.

We offer evidence that our findings are consistent with a skewness-related interpretation of the failure of UIP conditional on unconventional monetary policy surprises. During the ZLB, monetary policy easings shift skewness in the direction of dollar depreciations. In equilibrium, these should reduce the foreign currency risk premium, as conventionally defined. We also investigate whether the decline in the foreign exchange risk premium could result from a liquidity channel. We find some evidence that unconventional easing surprises lower the demand for the liquidity of short-term U.S. Treasuries amid improved market functioning. This too should lower the foreign exchange risk premium, and is thus consistent with our VAR results. 


\section{Table 1: Effects of U.S. Monetary Policy Shock on Foreign Ten-Year Term Premia (in basis points)

\begin{tabular}{lcc}
\hline \hline & Point Estimate & Confidence Interval \\
\hline United Kingdom & -12.5 & $(-14.9,-10.1)$ \\
Germany & -11.4 & $(-12.9,-10.1)$ \\
Japan & -4.1 & $(-4.7,-3.3)$ \\
\hline \hline
\end{tabular}

Notes: The table reports the posterior median and $68 \%$ Bayesian confidence intervals for the effects of a monetary policy shock that lowers the U.S. five-year yield by 25 basis points on the ten-year term premium in the United Kingdom, Germany and Japan.

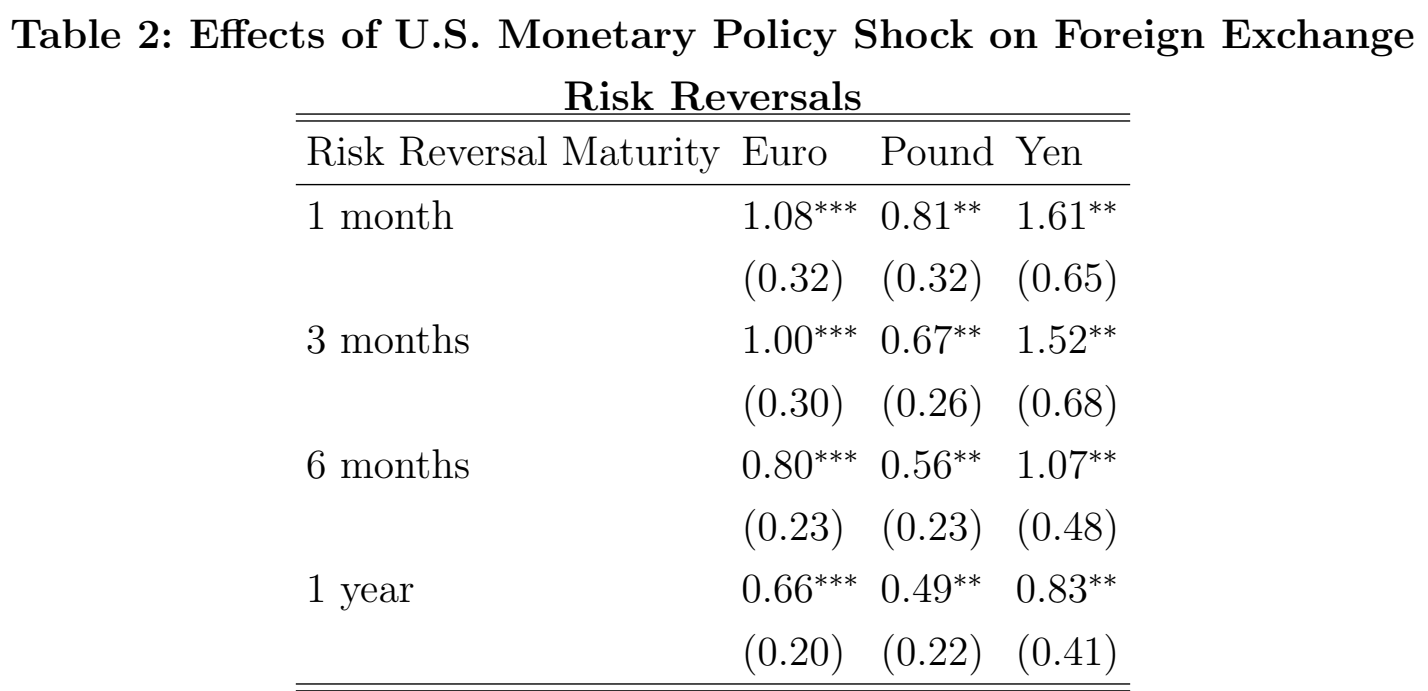

Notes: We measure monetary policy surprises as minus the intraday changes in the five-year Treasury futures yield from 15 minutes before FOMC announcements to 1 hour and 45 minutes afterwardspositive values reflect easing surprises. We then regress the two-day change in 25 delta risk reversals for each currency (viz-a-viz the dollar) and each maturity on these monetary policy surprises. Monetary policy surprises are measured in percentage points, while risk-reversals represent the differences in annualized volatility, also in percentage points, implied by out-of-the-money call and put options. The regression is run over all 69 FOMC announcements from October 2008 to December 2015. The regressions are run without constants. Robust standard errors are in parentheses. All currencies are defined as dollars per unit foreign currency, so that a positive coefficient means that a monetary policy easing changes the options-implied skewness in the direction of dollar depreciation. One, two and three asterisks denote significance at 10,5 and 1 percent levels, respectively. 
Table 3: Effects of U.S. Monetary Policy Shock on Domestic Term

\begin{tabular}{|c|c|c|}
\hline \multicolumn{3}{|c|}{ Premia (in basis points) } \\
\hline & Point Estimate & Confidence Interval \\
\hline Five-year & -21.3 & $(-22.8,-18.9)$ \\
\hline Ten-year & -21.6 & $(-22.7,-20.4)$ \\
\hline
\end{tabular}

Notes: The table reports the posterior median and $68 \%$ Bayesian confidence intervals for the effects of a monetary policy shock that lowers the U.S. five-year yield by 25 basis points on the five- and ten-year U.S. term premium.

Table 4: Effects of U.S. Monetary Policy Shock on Foreign Ten-Year Term Premia in the pre-ZLB era (in basis points)

\begin{tabular}{|c|c|c|}
\hline & Point Estimate & Confidence Interval \\
\hline United Kingdom & -9.4 & $(-12.9,-6.7)$ \\
\hline Germany & -6.6 & $(-10.1,-3.3)$ \\
\hline Japan & -0.9 & $(-2.5,1.0)$ \\
\hline
\end{tabular}

Notes: As for Table 1, except over the pre-ZLB period. 
Figure 1: Effects of U.S. Monetary Policy Shock on Exchange Rates
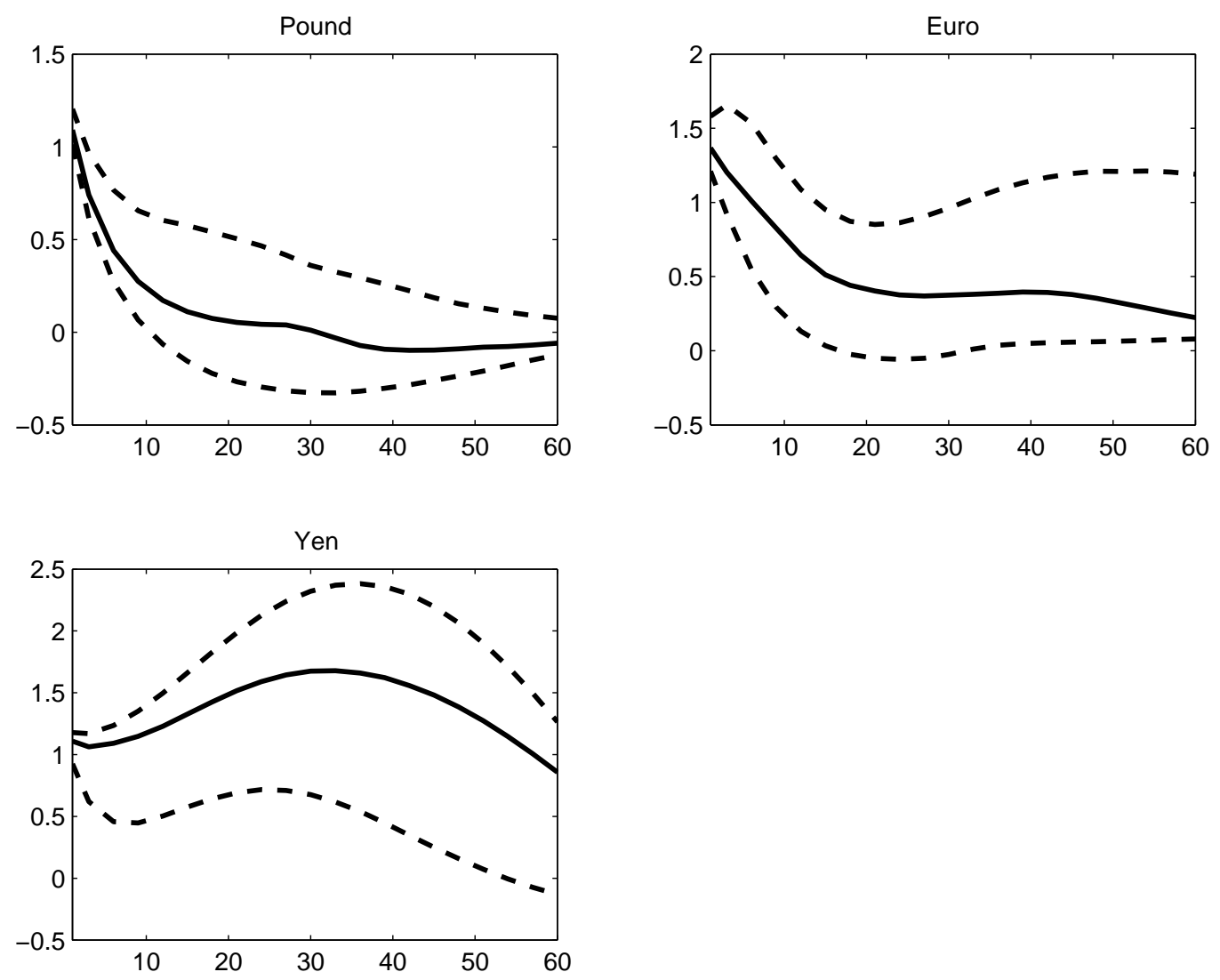

Note: This figure plots the posterior median effects of a monetary policy shock that lowers the U.S. five-year yield by 25 basis points on exchange rates (in percentage points, measured as dollars per unit of foreign currency) over the subsequent 60 months. The dashed lines are Bayesian 68 percent confidence intervals. 
Figure 2: Effects of U.S. Monetary Policy Shock on Foreign Interest Rates
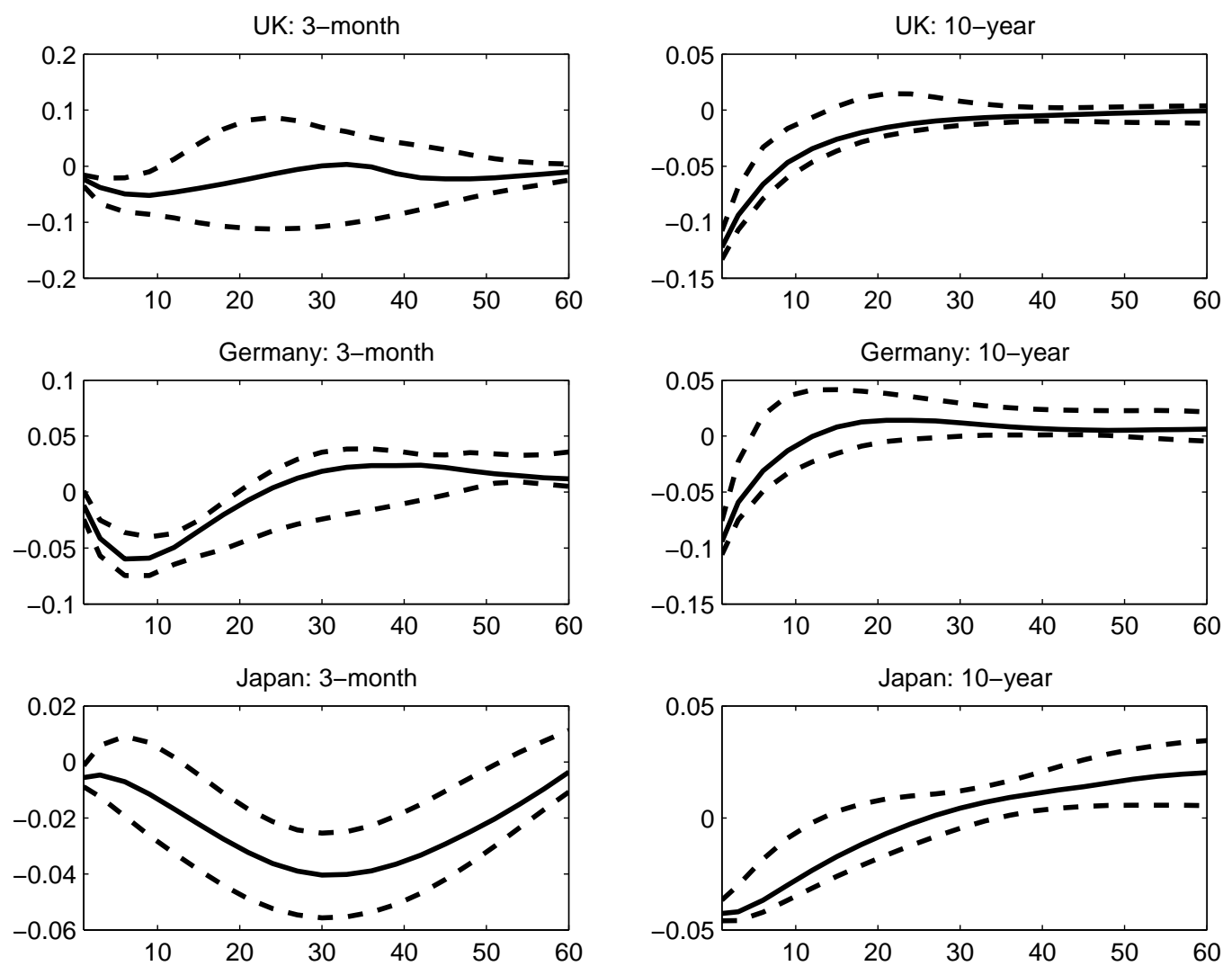

NotE: This figure plots the posterior median effects of a monetary policy shock that lowers the U.S. five-year yield by 25 basis points on foreign interest rates (in percentage points) over the subsequent 60 months. The dashed lines are Bayesian 68 percent confidence intervals. 


\section{Figure 3: Effects of U.S. Monetary Policy Shock on Foreign Exchange Risk Premium}
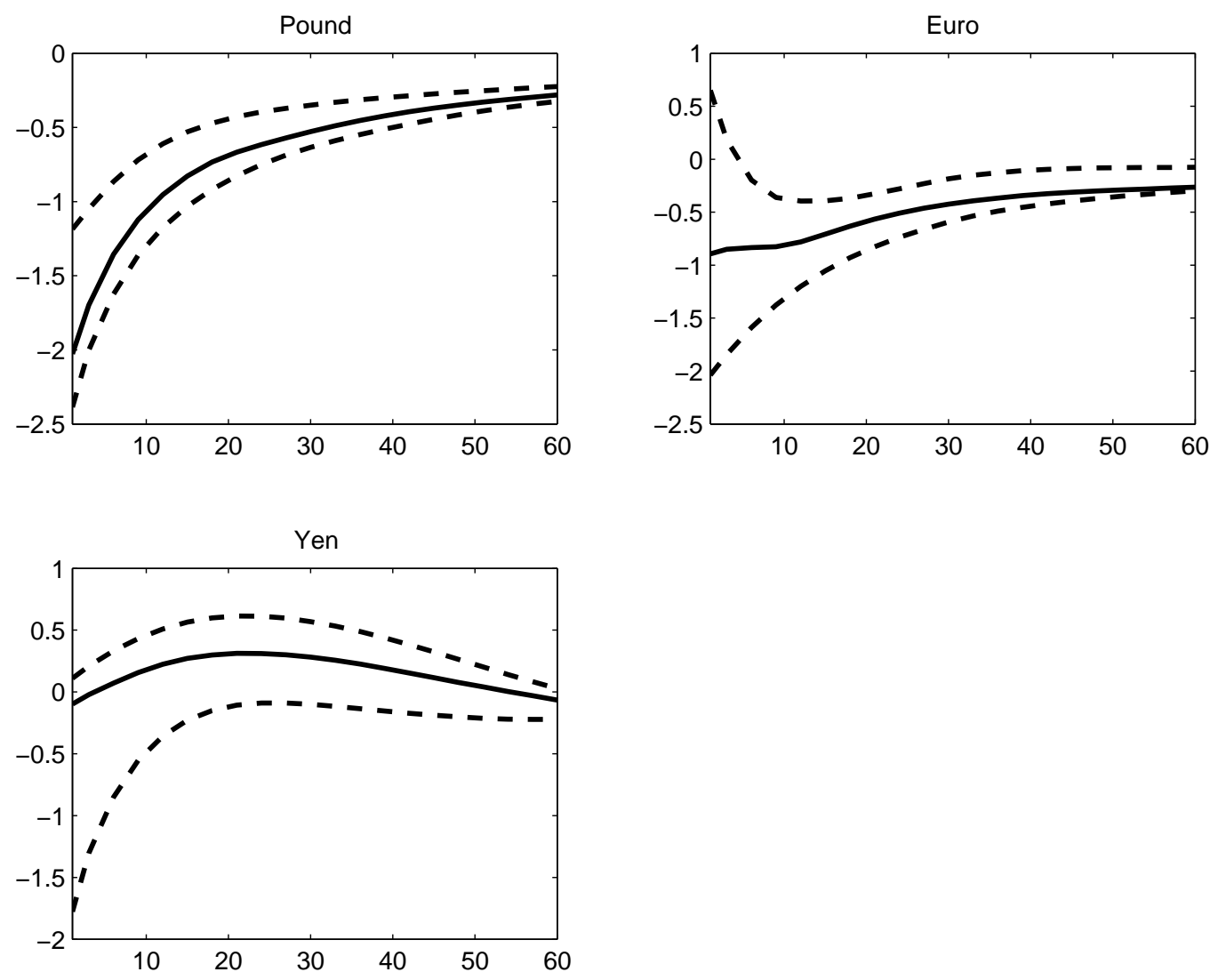

NotE: This figure plots the posterior median effects of a monetary policy shock that lowers the U.S. five-year yield by 25 basis points on the foreign exchange risk premium (as defined in equation (6) in the text, and measured in percentage points) over the subsequent 60 months. The dashed lines are Bayesian 68 percent confidence intervals. 
Figure 4: Effects of U.S. Monetary Policy Shock on Exchange Rates: Pre-ZLB Era
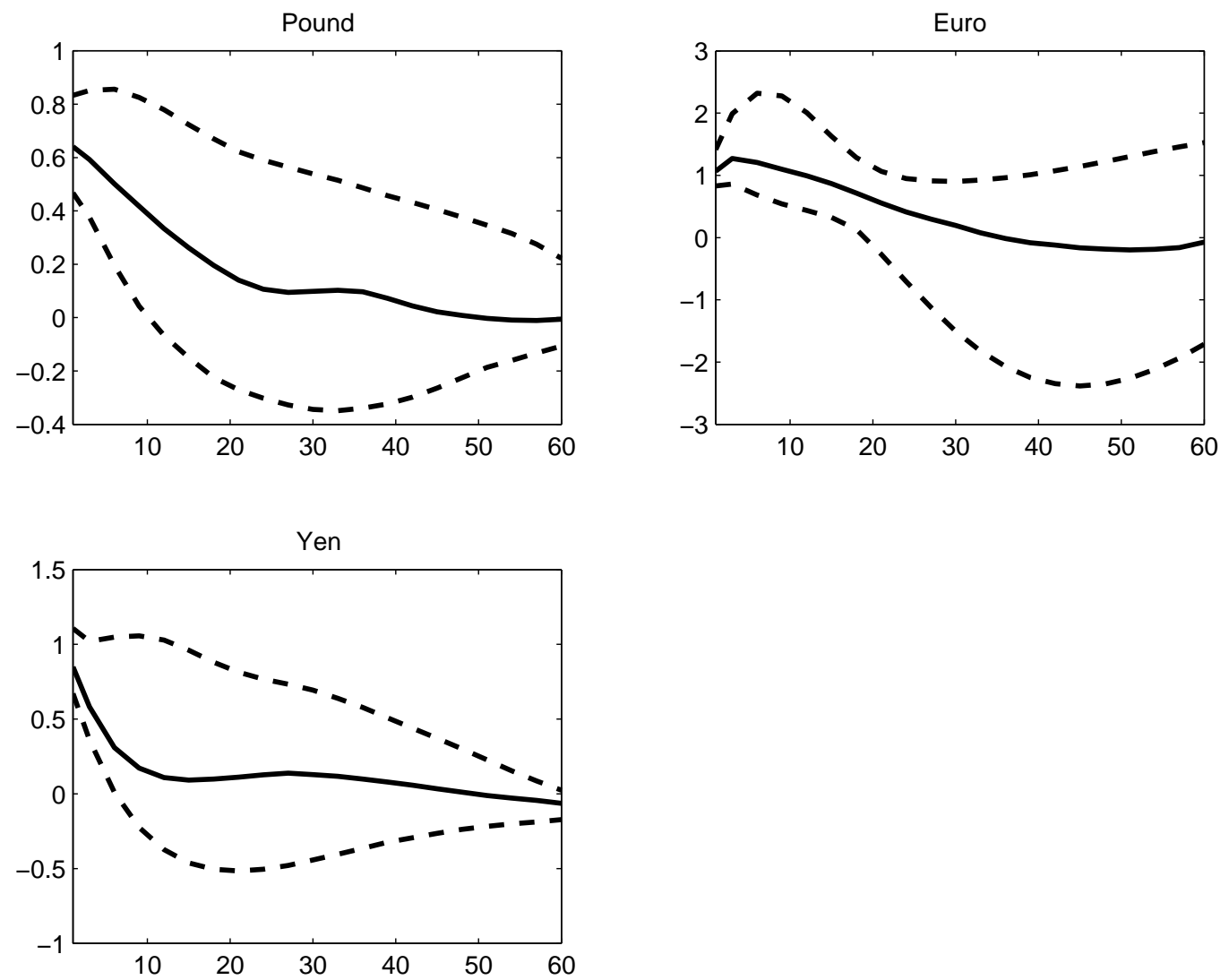

NoTE: This figure plots the posterior median effects of a monetary policy shock that lowers the U.S. five-year yield by 25 basis points on exchange rates (in percentage points, measured as dollars per unit of foreign currency) over the subsequent 60 months. The monetary policy shock is identified over the pre-ZLB period using FOMC-day intraday changes in the fourth eurodollar futures contract as the external instrument. The dashed lines are Bayesian 68 percent confidence intervals. 


\section{Figure 5: Effects of U.S. Monetary Policy Shock on Foreign Interest}

\section{Rates: Pre-ZLB Era}
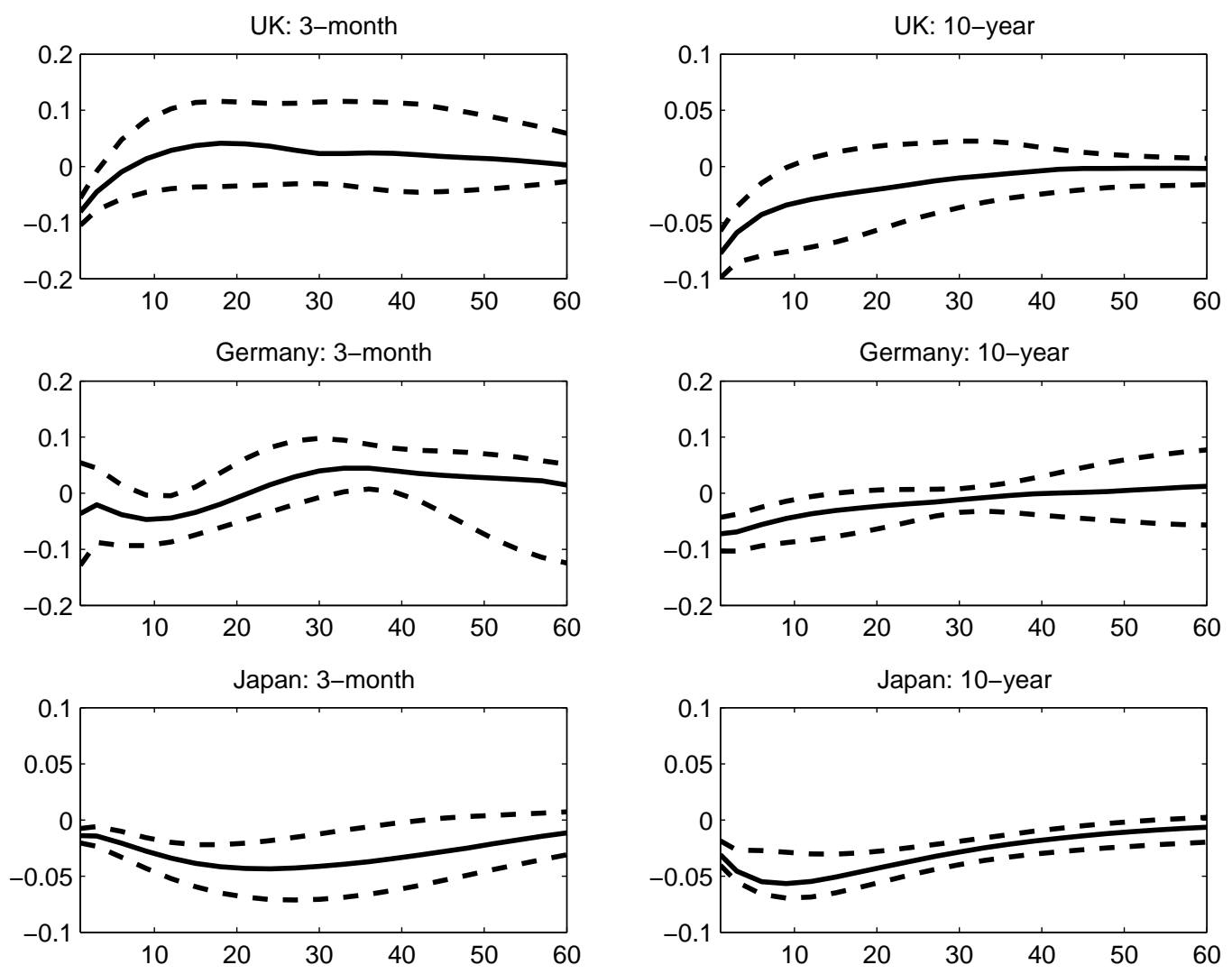

Note: This figure plots the posterior median effects of a monetary policy shock that lowers the U.S. five-year yield by 25 basis points on foreign interest rates (in percentage points) over the subsequent 60 months. The monetary policy shock is identified over the pre-ZLB period using FOMC-day intraday changes in the fourth eurodollar futures contract as the external instrument. The dashed lines are Bayesian 68 percent confidence intervals. 


\section{Figure 6: Effects of U.S. Monetary Policy Shock on Foreign Exchange}

Risk Premium: Pre-ZLB Era
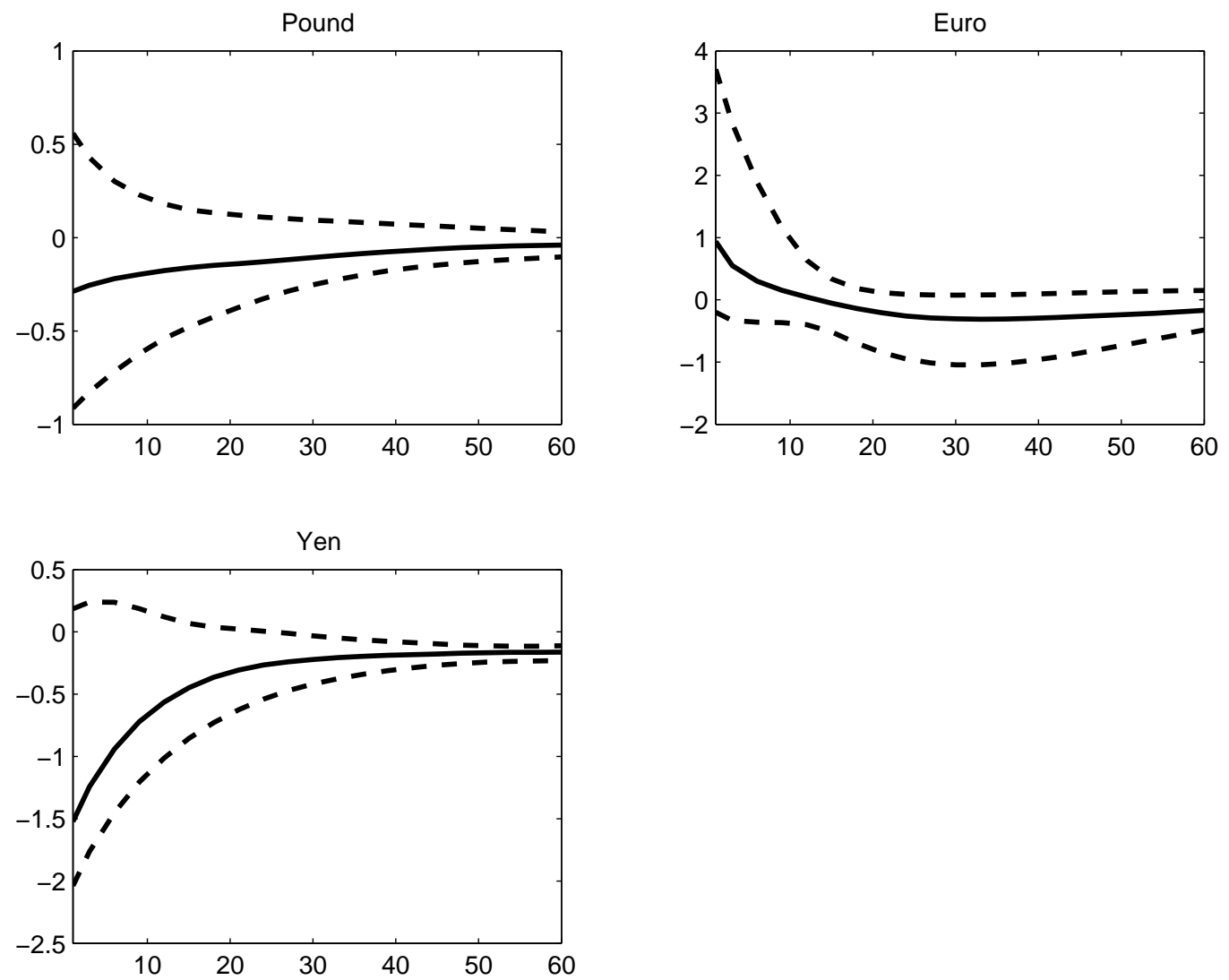

Note: This figure plots the posterior median effects of a monetary policy shock that lowers the U.S. five-year yield by 25 basis points on the foreign exchange risk premium (as defined in the text, and measured in percentage points) over the subsequent 60 months. The monetary policy shock is identified over the pre-ZLB period using FOMCday intraday changes in the fourth eurodollar futures contract as the external instrument. The dashed lines are Bayesian 68 percent confidence intervals. 
Figure 7: Effects of Non-U.S. Monetary Policy Shocks on Exchange Rates
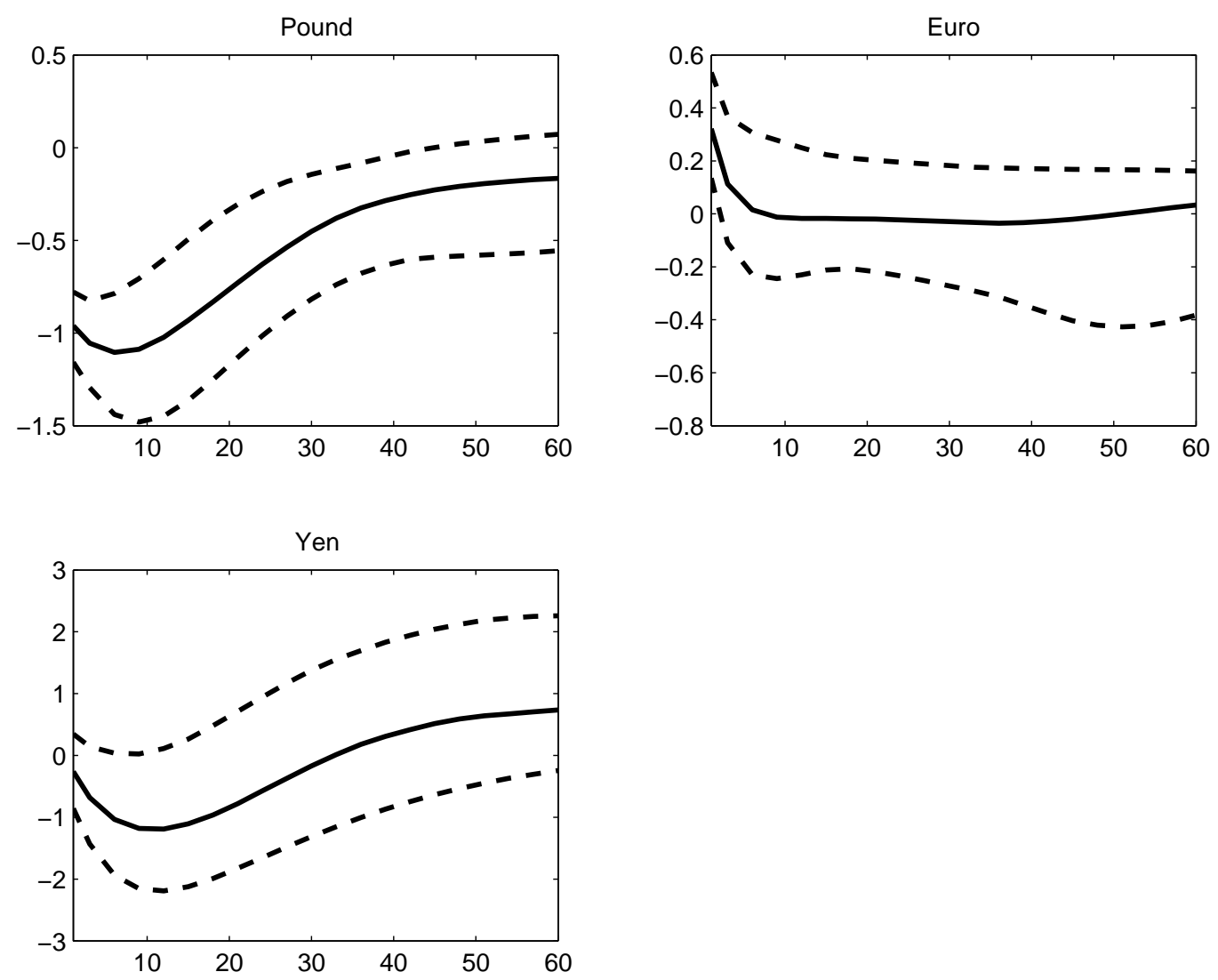

Note: This figure plots the posterior median effects of a monetary policy shock that lowers the U.K., Italian or Japanese five-year yield by 25 basis points on the respective exchange rates (in percentage points, measured as unit of foreign currency per dollar) over the subsequent 60 months. The dashed lines are Bayesian 68 percent confidence intervals. 
Figure 8: Effects of Non-U.S. Monetary Policy Shocks on U.S. Interest

\section{Rates}
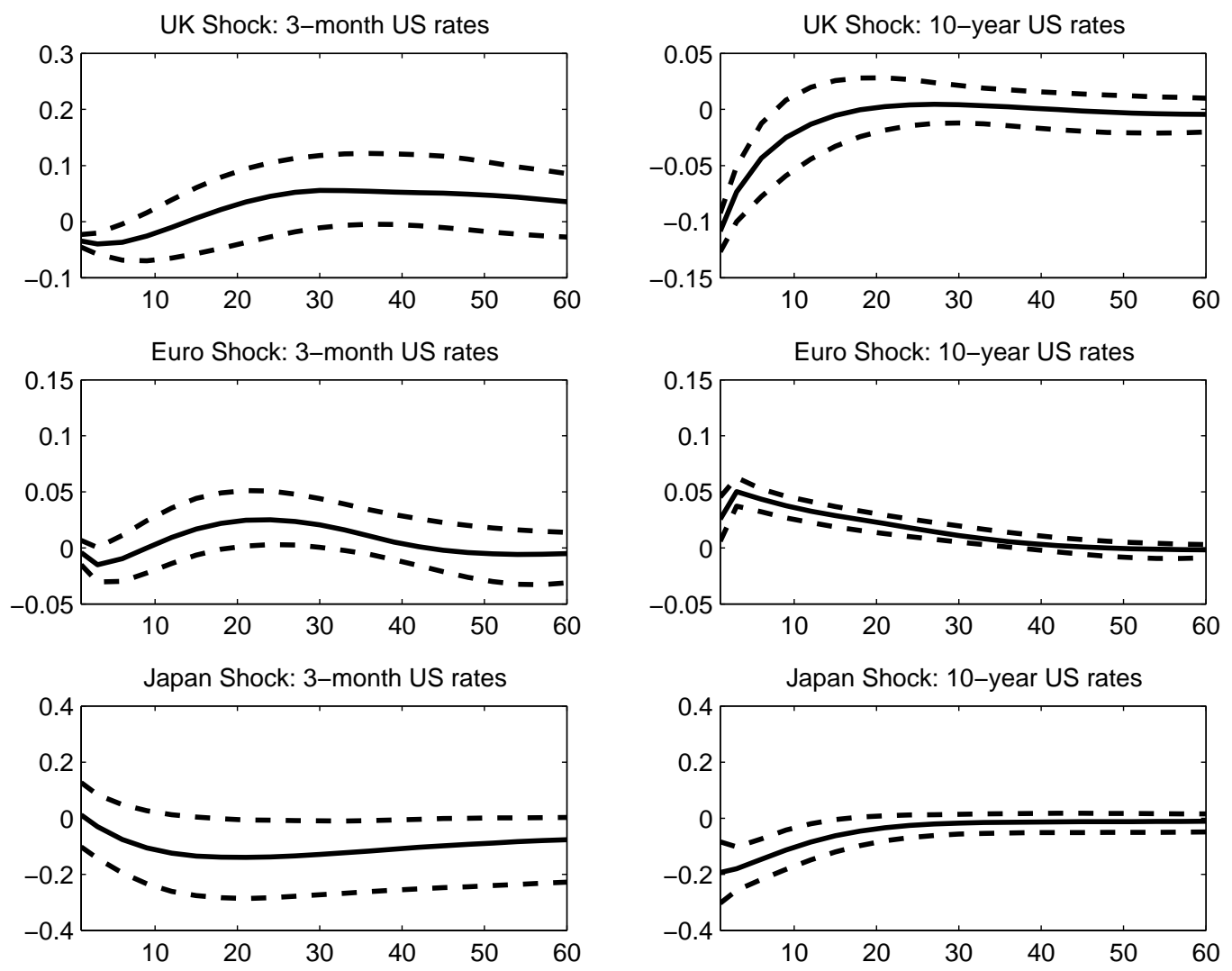

Note: This figure plots the posterior median effects of a monetary policy shock that lowers the U.K., Italian or Japanese five-year yield by 25 basis points on U.S. interest rates over the subsequent 60 months. The dashed lines are Bayesian 68 percent confidence intervals. 


\section{Figure 9: Effects of Non-U.S. Monetary Policy Shocks on Foreign Exchange Risk Premium}
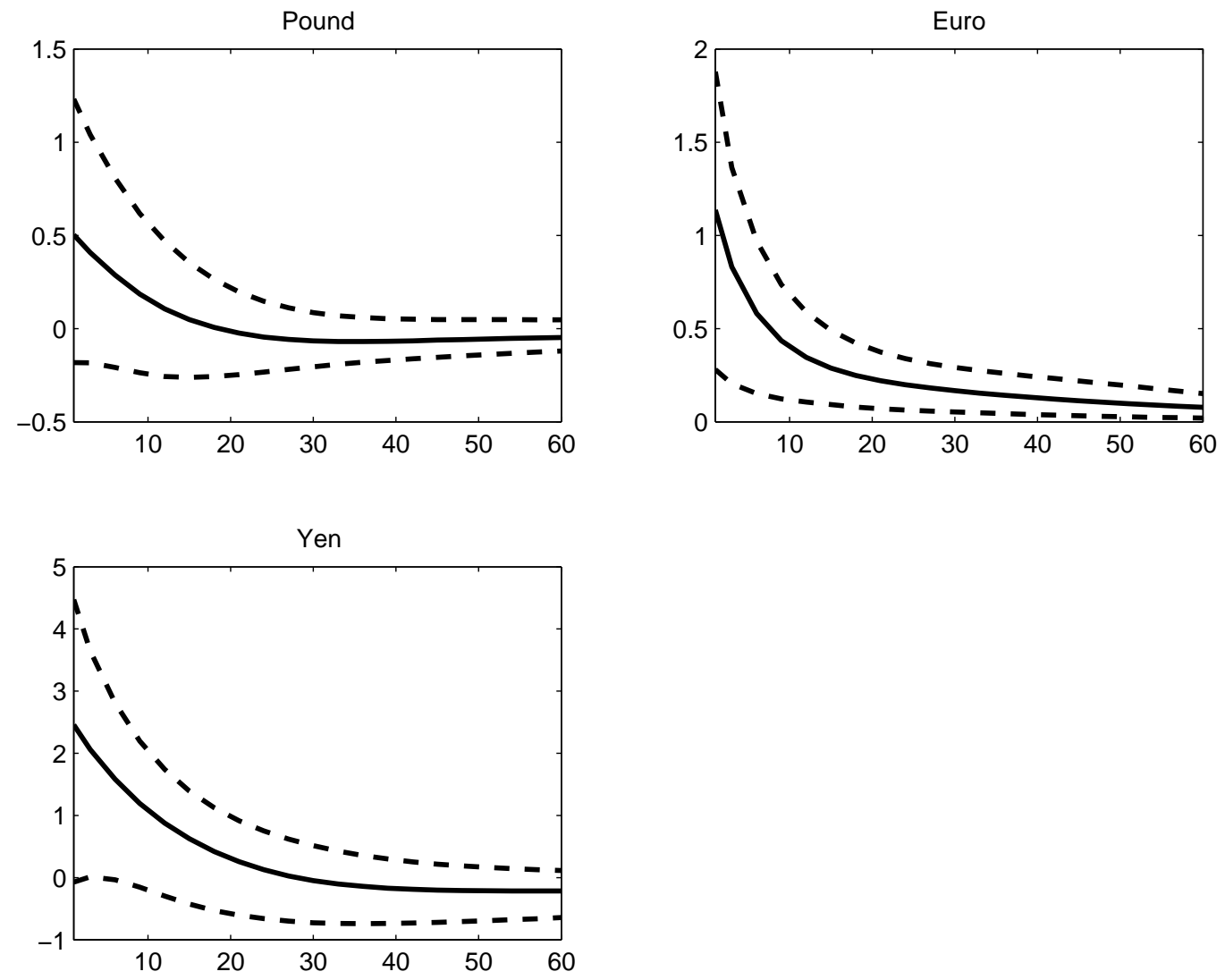

Note: This figure plots the posterior median effects of a monetary policy shock that lowers the U.K., Italian or Japanese five-year yield by 25 basis points on the respective foreign exchange risk premia (as defined in the text, and measured in percentage points) over the subsequent 60 months. The foreign exchange risk premium is defined from the perspective of the United Kingdom, euro area or Japan. The dashed lines are Bayesian 68 percent confidence intervals. 


\section{References}

Andersen, Torben, Tim Bollerslev, Francis X. Diebold, and Clara Vega, "Micro effects of macro announcements: real-time price discovery in foreign exchange," American Economic Review, 2003, 93, 3862.

_ , _ , _, and _ , "Real-time price discovery in global stock, bond and foreign exchange markets," Journal of International Economics, 2007, 73, 251277.

Backus, David K., Federico Gavazzoni, Chris Telmer, and Stanley E. Zin, "Montary Policy and the Uncovered Interest Rate Parity Puzzle," 2010. NBER Working Paper 16218.

Bjornland, Hilde C., "Monetary Policy and Exchange Rate Overshooting: Dornbusch was Right After All," Journal of International Economics, 2009, 79.

Bouakez, Hafedh and Michel Normandin, "Fluctuations in the Foreign Exchange Market: How Important are Monetary Policy Shocks?," Journal of International Economics, 2010, 81, 139153.

Bredin, Don, Stuart Hyde, and Gerard OReilly, "Monetary Policy Surprises and International Bond Markets," Journal of International Money and Finance, 2010, 29, 9881002 .

Brunnermeier, Markus, Stefan Nagel, and Lasse Pedersen, "Carry Trades and Currency Crashes," NBER Macroeconomics Annual, 2009, 23, 313-347.

Caldara, Dario and Edward Herbst, "Monetary Policy, Real Activity and Credit Spreads: Evidence from Bayesian Proxy SVARs," 2016. Working Paper.

Christensen, Jens H.E. and Glenn D. Rudebusch, "The Response of Interest Rates to US and UK Quantitative Easing," Economic Journal, 2012, 122, F385F414.

Christiano, Lawrence J., Roberto Motto, and Massimo Rostagno, "Risk Shocks," American Economic Review, 2014, 104, 27-65.

Ehrmann, Michael and Marcel Fratzscher, "Monetary Policy Announcements and Money Markets: A Transatlantic Perspective," International Finance, 2003, 6, $1-20$. 
_ and _, "Equal Size, Equal Role? Interest Rate Interdependence between the Euro Area and the United States," Economic Journal, 2005, 115, 930-950.

Eichenbaum, Martin and Charles L. Evans, "Some Empirical Evidence on the Effects of Shocks to Monetary Policy on Exchange Rates," Quarterly Journal of Economics, 1995, 110, 975-1010.

Engel, Charles, "The forward discount anomaly and the risk premium: A survey of recent evidence," Journal of Empirical Finance, 1996, 3, 123191.

_ , "Exchange Rates and Interest Parity," Handbook of International Economics, 2013.

_, American Economic Review, forthcoming. Exchange Rates, Interest Rates, and the Risk Premium.

Fama, Eugene, "Spot and Forward Exchange Rates," Journal of Monetary Economics, 1984, 14, 319-338.

Farhi, Emmanuel and Xavier Gabaix, "Rare Disasters and Exchange Rates," 2014. Working Paper.

Faust, Jon, "The Robustness of Identified VAR Conclusions about Money," Carnegie Rochester Series on Public Policy, 1998, 49, 207-244.

- and John Rogers, "Monetary policy's role in exchange rate behavior," Journal of Monetary Economics, 2003, 50, 1403-1424.

_, John H. Rogers, Shing-Yi Wang, and Jonathan H. Wright, "The highfrequency response of exchange rates and interest rates to macroeconomic announcements," Journal of Monetary Economics, 2007, 54, 10511068.

_, John Rogers, Eric T. Swanson, and Jonathan H. Wright, "Identifying the Effects of Monetary Policy on Exchange Rates Using High Frequency Data," Journal of the European Economic Association, 2003, 1, 1031-1057.

Gagnon, Joseph, Matthew Raskin, Julie Remache, and Brian Sack, "LargeScale Asset Purchases by the Federal Reserve: Did They Work?," International Journal of Central Banking, 2011, 7, 3-44. 
Gertler, Mark and Peter Garadi, "Monetary Policy Surprises, Credit Costs and Economic Activity," American Economic Journal: Macroeconomics, 2015, 7, 4476.

Gilchrist, Simon, Vivian Yue, and Egon Zakrajšek, "US Monetary Policy and Foreign Bond Yields," 2014. Working Paper.

Gürkaynak, Refet S., Brian Sack, and Eric T. Swanson, "Do Actions Speak Louder Than Words? The Response of Asset Prices to Monetary Policy Actions and Statements," International Journal of Central Banking, 2005, 1, 55-93.

Hausman, Joshua and Jon Wongswan, "Global Asset prices and FOMC Announcements," Journal of International Money and Finance, 2011, 30, 547571.

International Monetary Fund, "Unconventional Monetary Policies-Recent Experience and Prospects," 2013.

Kiley, Michael T., "Exchange Rates, Monetary Policy Statements, and Uncovered Interest Parity: Before and After the Zero Lower Bound," 2013. Finance and Economics Discussion Series, 2013-17.

Kim, Soyoung, "International transmission of US monetary policy shocks: Evidence from VARs," Journal of Monetary Economics, 2001, 48, 339-372.

- and Nouriel Roubini, "Exchange Rate Anomalies in the Industrial Countries: A Solution with a Structural VAR Approach," Journal of Monetary Economics, 2000, 45, 561-586.

Krishnamurthy, Arvind and Annette Vissing-Jorgenson, "The Effects of Quantitative Easing on Long-term Interest Rates," Brookings Papers on Economic Activity, 2011, 2, 215-265.

Kuttner, Kenneth, "Monetary Policy Surprises and Interest Rates: Evidence from the Fed Funds Futures Market," Journal of Monetary Economics, 2001, 47, 523544 .

Mertens, Karel and Morten O. Ravn, "The Dynamic Effects of Personal and Corporate Income Tax Changes in the United States," American Economic Review, 2013, 103, 1212-1247. 
Olea, José L.M., James H. Stock, and Mark W. Watson, "Inference in Structural VARs with External Instruments," 2013. Working Paper.

Rogers, John, Chiara Scotti, and Jonathan H. Wright, "Evaluating AssetMarket Effects of Unconventional Monetary Policy: A Multi-Country Review," Economic Policy, 2014, 29, 3-50.

Scholl, Almuth and Harald Uhlig, "New Evidence on the Puzzles: Results from Agnostic Identification on Monetary Policy and Exchange Rates," Journal of International Economics, 2008, 76, 113.

Stock, James H. and Mark. W. Watson, "Disentangling the Channels of the 2007-2009 Recession," Brookings Papers on Economic Activity, 2012, 1, 81-156.

_ and Motohiro Yogo, "Testing for Weak Instruments in Linear IV Regression," in Donald W.K. Andrews and James H. Stock, eds., Identification and Inference for Econometric Models: Essays in Honor of Thomas Rothenberg, Cambridge University Press 2005.

_ , Jonathan H. Wright, and Motohiro Yogo, "A Survey of Weak Instruments and Weak Identification in Generalized Method of Moments," Journal of Business and Economic Statistics, 2002, 20, 518-529.

Uhlig, Harald, "What are the Effects of Monetary Policy on Output? Results from an Agnostic Identification Procedure," Journal of Monetary Economics, 2005, 52, $381-419$.

Wright, Jonathan H., "Term Premia and Inflation Uncertainty: Empirical Evidence from an International Panel Dataset," American Economic Review, 2011, $101,1514-1534$.

_, "What does Monetary Policy do to Long-term Interest Rates at the Zero Lower Bound?," Economic Journal, 2012, 122, F447-F466. 